\title{
The Effect of Workload on the Performance of Nurses in the Inpatient Installation of RSUP Dr. Tadjuddin Chalid Makassar
}

\author{
Andi Niartiningsih ${ }^{1}$, Anis Khairunnisa ${ }^{1}$, Nurul Hidayah Nur ${ }^{1}$ \\ Email: andiniar30@gmail.com \\ ${ }^{1}$ Hospital Administration Study Program, Faculty of Health Sciences, Cokroaminoto \\ University of Makassar
}

\begin{abstract}
Performance is the quality and amount of work accomplished by an employee in carrying out his obligations in line with those assigned to him. The purpose of this study is to determine the influence of workload on nurses' performance at Dr. RSUP Tajuddin Chalid Makassar's Inpatient Installation. This is a quantitative form of research that employs an observational study design with a cross sectional design. The survey sampled nurses at Dr. RSUP. Tajuddin Chalid Makassar's Inpatient Installation, totalling 73 responses. The findings indicated that time load had an influence on nurses' performance, as did physical strain. Psychological stress has an influence on nurses' performance at Dr. RSUP. Tajuddin Chalid Makassar's Inpatient Installation. Thus, it is hoped that hospital administration will enhance nurses' knowledge and skills to compensate for the difficult work by providing training, recognizing the importance of improving nursing management through the development of SOPs, particularly the division of tasks and working hours of nurses, which can be adjusted to the nurse's workload.
\end{abstract}

Keywords: Workload, Performance, Nurses, Inpatient, Hospital

Received : October 27, 2021

Received in Revised: November 25, 2021

Accepted: December 17, 2021

\section{Introduction}

According to Mangkunegara (2013), performance is defined as the quality and amount of work accomplished by an employee in carrying out his duties in line with the obligations assigned to him. The amount or quality of things produced or services rendered by someone who performs a job is referred to as performance (Luthans, 2005).

According to Griffiths et al. (2008), there are several variables that contribute to the risk of declining performance, one of which is an excessive workload for the available staff/nurses. Meanwhile, Yang (2003) in Armstrong (2009) implies that nurses' workload is a predictor of decreased performance. According to Marquis and Houston (2000), a nurse's workload is defined as all activities or tasks performed by a nurse while serving in a nursing service unit. The workload is often expressed in terms of patient days, which relates to the number of operations and client visits. Additionally, workload is defined as the entire amount of nursing time spent directly or indirectly delivering nursing services to clients, as well as the number of nurses required to offer these services (Gaudine, 2000).

Workload is a term that occurs as a result of restricted capacity for information processing. These constraints might obstruct the attainment of job objectives and result in gaps. This discrepancy results in performance failure. As a result, an evaluation is necessary before adopting an acceptable system for nurses to ensure that their workloads are not excessive. Effective human resource planning is necessary to ensure that nurses' workloads do not exceed

Copyright @ 2021 , International Journal Papier Advance and Scientific Review, Under the license CC BY-SA 4.0

DOI: https://doi.org/10.47667/ijpasr.v2i2.126 
their capability while still providing their best performance in treating patients, and, of course, to improve the quality of services, particularly those provided by inpatient nurses.

Other workload issues confront nurses when they believe the quantity of nurses available is not related to the amount of work that needs to be performed, forcing them to work outside of normal business hours. As a result of their frequent health issues, which include trouble sleeping at night, they are frequently lethargic and unable to focus at work, quickly weary, and easily offended for no apparent reason. (2016) (Samiadji). Iswatun's (2013) research demonstrates a substantial relationship between workload and nursing performance. Then there is Sihotang (2011), which demonstrates that workload has an effect on nurses' performance.

In 2004, the Directorate of Nursing Services of the Ministry of Health conducted research in partnership with the WHO (World Health Organization) in many provinces in Indonesia, including East Kalimantan, North Sumatra, North Sulawesi, West Java, and DKI Jakarta. ,9\% of nurses have never had training, 39.8\% of nurses in hospitals conduct non-nursing jobs, $47.4 \%$ of nurses do not have clear and written job descriptions, and there is no routine monitoring and assessment of nurses' performance. precisely (Kemenkes RI, 2010).

The results of the evaluation of nurses' performance in hospitals were based on the standards of the Indonesian National Nurses Association (PPNI) in 2010. It was discovered that in 2018, the level of performance of nurses at Dr. Tadjuddin Chalid Makassar's Inpatient Installation was an average of 87.8 percent, which means that it is not in accordance with nursing care standards (100 percent) with details of nursing care, such as

Thus, the researcher aims to do more study of the influence of the workload variable as the dependent variable, as workload is believed to affect nurses' performance, allowing hospitals to deliver high-quality health care.

\section{Methods}

Between November 2020 and January 2021, this research was undertaken at Dr. Tadjuddin Chalid Makassar. The research is quantitative in nature and employs an observational study technique with a cross sectional design. The population of this study consisted of all nurses who provided medical services at Dr. RSUP. Tadjuddin Chalid Makassar's Inpatient Installation, which had a total of 136. This survey sampled a total of 73 respondents. The data collecting tool is a questionnaire, with the independent factors being time burden, physical burden, and psychological pressure load, and the dependent variable being nurse performance. Univariate analysis was utilized to gain an overview of the research topic by detailing each variable employed in the study and the respondents' characteristics. The univariate analysis included a descriptive examination of respondents' characteristics, a descriptive examination of research factors, and a crosstabulation examination of respondents' characteristics and research variables. Bivariate analysis was used to determine the influence of two variables, namely the independent and dependent variables. The chi square test was utilized for statistical analysis, while logistic regression analysis was employed for multivariate analysis.

\section{Results and Discussion}

Table 1. Distribution of the Characteristics of Doctor Respondents at Dr. RSUP. Tadjuddin Year 2021

\begin{tabular}{|c|c|c|}
\hline \multirow{2}{*}{ Characteristic } & \multicolumn{2}{|c|}{ Research Sample } \\
\cline { 2 - 3 } & $\mathbf{N}$ & $\%$ \\
\hline \multicolumn{2}{|c|}{ Age (years) } \\
\hline
\end{tabular}




\begin{tabular}{|l|l|l|}
\hline $20-35$ & 21 & 28.77 \\
\hline $35-45$ & 33 & 45.21 \\
\hline$>45$ & 19 & 26.03 \\
\hline Sum & $\mathbf{7 3}$ & $\mathbf{1 0 0 . 0 0}$ \\
\hline \multicolumn{2}{|c|}{ Gender } \\
\hline Man & 24 & 32.88 \\
\hline Woman & 49 & 67.12 \\
\hline Sum & $\mathbf{7 3}$ & $\mathbf{1 0 0 . 0 0}$ \\
\hline \multicolumn{3}{|c|}{} \\
\hline $3-5$ & 6 & 8.22 \\
\hline $6-8$ & 47 & 64.38 \\
\hline$>8$ & 20 & 27.40 \\
\hline Sum & $\mathbf{7 3}$ & $\mathbf{1 0 0 . 0 0}$ \\
\hline \multicolumn{3}{|c|}{ The Last Education } \\
\hline Bachelor of Nursing & 42 & 57.53 \\
\hline Ners & 31 & 42.47 \\
\hline \multicolumn{2}{|c|}{ Staffing Status } \\
\hline Honor & 20 \\
\hline PNS & 53 & 27.40 \\
\hline Sum & $\mathbf{7 3}$ \\
\hline
\end{tabular}

\section{Source: Primary Data}

The frequency distribution in Table 1 is based on the characteristics of the sample at the study site, the majority of whom are between the ages of 35 and 45, with as many as 33 respondents (45.21 percent ). In terms of gender, the majority of responders were female, totaling 49. (67.12 percent ). According to their tenure of employment, the majority of respondents worked for six to eight years, with as many as 47 respondents (64.38 percent ). According to their most recent education, all respondents had a bachelor's degree, with as many as 42 respondents having a master's degree (57.53 percent ). According to their job status, the majority of respondents, 53, were public servants (72.60 percent ).

Table 2. Distribution of respondents based on research variables at Tarakan Hospital in 2021

\begin{tabular}{|l|c|c|}
\hline \multirow{2}{*}{ Variable } & Research Sample \\
\cline { 2 - 3 } & Time Load & \% \\
\hline \multicolumn{3}{|c|}{ Time } \\
Low & 36 & 49.32 \\
\hline Tall & 37 & 50.68 \\
\hline Sum & 73 & 100.00 \\
\hline \multicolumn{3}{|c|}{ Physical Load } \\
\hline Low & 16 & 21.92 \\
\hline Tall & 77 & 78.08 \\
\hline Sum & 73 & 100.00 \\
\hline \multicolumn{3}{|c|}{ Burden of Psychological Pressure } \\
\hline Low & 31 & 78.08 \\
\hline Tall & 42 & 57.9 \\
\hline Sum & 73 & 100.00 \\
\hline \multicolumn{3}{|c|}{ Performance } \\
\hline
\end{tabular}




\begin{tabular}{|l|c|c|}
\hline Low & 44 & 60.27 \\
\hline Tall & 29 & 39.73 \\
\hline Sum & 73 & 100.00 \\
\hline
\end{tabular}

Table 2 summarizes respondents' ratings of the research factors as a percentage. The majority of respondents said that they were in the area of time load (50.68 percent), physical burden (78.08 percent), psychological pressure burden (57.9 percent), and nursing performance (poor category) (60.27 percent ).

Table 3. Analysis of the Effect of Independent Variables with Dependent Variables

\begin{tabular}{|c|c|c|c|c|c|c|c|}
\hline \multirow{3}{*}{ Time Load } & \multicolumn{4}{|c|}{ Nurse Performance } & \multirow{2}{*}{\multicolumn{2}{|c|}{ Sum }} & \multirow{3}{*}{$p$} \\
\hline & \multicolumn{2}{|c|}{ Tall } & \multicolumn{2}{|c|}{ Low } & & & \\
\hline & $\mathbf{n}$ & $\%$ & $\mathbf{n}$ & $\%$ & $\mathbf{n}$ & $\%$ & \\
\hline High & 25 & 58.13 & 18 & 41.87 & 43 & 100.00 & \multirow{3}{*}{0.000} \\
\hline Low & 19 & 63.33 & 11 & 36.67 & 30 & 100.00 & \\
\hline Total & 44 & 47.90 & 29 & 52.10 & 73 & 100.00 & \\
\hline \multirow{3}{*}{ Physical Load } & \multicolumn{4}{|c|}{ Nurse Performance } & \multirow{2}{*}{\multicolumn{2}{|c|}{ Sum }} & \multirow{3}{*}{$p$} \\
\hline & \multicolumn{2}{|c|}{ Tall } & \multicolumn{2}{|c|}{ Low } & & & \\
\hline & $\mathbf{n}$ & $\%$ & $\mathbf{n}$ & $\%$ & $\mathbf{n}$ & $\%$ & \\
\hline High & 36 & 76.59 & 11 & 26.27 & 47 & 100.00 & \multirow{3}{*}{0.000} \\
\hline Low & 16 & 61.53 & 10 & 38.46 & 26 & 100.00 & \\
\hline Total & 52 & 47.90 & 21 & 36.67 & 73 & 100.00 & \\
\hline \multirow{3}{*}{ Physical Load } & \multicolumn{4}{|c|}{ Nurse Performance } & \multirow{2}{*}{\multicolumn{2}{|c|}{ Sum }} & \multirow{3}{*}{$p$} \\
\hline & \multicolumn{2}{|c|}{ Tall } & \multicolumn{2}{|c|}{ Low } & & & \\
\hline & $\mathbf{n}$ & $\%$ & $\mathbf{n}$ & $\%$ & $\mathbf{n}$ & $\%$ & \\
\hline High & 25 & 58.13 & 18 & 41.87 & 43 & 100.00 & \multirow{3}{*}{0.000} \\
\hline Low & 19 & 63.33 & 11 & 36.67 & 30 & 100.00 & \\
\hline Total & 44 & 47.90 & 29 & 52.10 & 73 & 100.00 & \\
\hline
\end{tabular}

The Independent Variable's influence on the Dependent Variable is seen in Table 3. The analysis's findings indicate that there is an impact of time load on nurse performance $(0.000)$, and that there is an effect of physical load on nurse performance (0.000). (0.000). There is an effect of psychological strain on nursing performance (0.000), at Dr. RSUP. Tajuddin Chalid Makassar's Inpatient Installation.

Table 4. Results of Logistic Regression Analysis on Nurse Performance at Dr. RSUP.

Tadjuddin Chalid Makassar

\begin{tabular}{|c|c|c|c|c|c|c|}
\hline Variable & B & S.E. & $\mathbf{t}$ & Df & Itself. & $\operatorname{Exp}(B)$ \\
\hline Time Load & .288 & .070 & 4.097 & 1 & 0.000 & 0.287 \\
\hline Physical Load & .274 & .122 & 2.251 & 1 & 0.026 & 0.208 \\
\hline Burden & .234 & .108 & 2.174 & 1 & 0.031 & 0.205 \\
\hline Psychological Pressure & & & & & & \\
\hline Constant & .464 & 0.130 & 3.572 & 1 & 0.000 & \\
\hline
\end{tabular}

The effect of concurrent time load, physical burden, and psychological pressure load on nursing performance is shown in Table 4. The value of the Standard Coefficient (Beta) at the hospital 
under study has a significant effect. According to Dr. Tajuddin Chalid, the most significant factor is the physical burden of 0.416 .

The research hypothesis 1 (H1) asserts that time burden has an influence on nursing performance. According to the statistical research, time load has an effect on the performance of nurses at Dr. RSUP. Tadjuddin Chalid. A significance score of 0.000 also indicates a substantial effect, implying that study hypothesis 1 (H1) is adopted in this circumstance.

The workload must be appropriate for the task executor's (nurse) capabilities in order to maintain adequate performance. Inadequate human resource management can result in subjective complaints, increasing workloads, ineffective and inefficient operations, and job unhappiness, all of which result in decreasing performance and productivity, as well as a decline in service quality. To further enhance personnel performance and management, the leadership of care must examine the appropriate balance of staff and workload for nurses. A heavy workload is mentally taxing, and it has the potential to impair nurses' performance.

The findings of this study corroborate Huey and Wickens's (1993) theory, which claims that when an employee's workload is excessive, mistakes occur as a result of the employee's incapacity to meet the demands of a critical task. Workload and performance can have a negative correlation, with more workload resulting in decreased performance. According to Shah et al. (2011), an increase in workload might result in a decline in performance. This study discovered a negative relationship between workload and employee performance, indicating that as workload grows, employee performance suffers.

According to the findings of the research, 44.91 percent of nurses agreed with the statement "I am bored when I am required to observe patients every hour," 47.31 percent agreed with the statement "I feel like my skills are rarely used," and 49.10 percent agreed with the statement "I occasionally feel confused with orders from my superiors." Reduced workload for nurses providing inpatient care, including physical, psychological, and work time pressures, can enhance inpatient care implementation performance. The physical toll on nurses is evident via extreme weariness at work. Psychological strain might be indicated by a sensation of being under pressure, inability of superiors to inspire nurses' work, and boredom with the work environment. The time strain is shown by the lengthy work hours and frequent shift changes that disrupt working time.

The second research hypothesis $(\mathrm{H} 2)$ indicates that physical burden has an influence on the performance of nurses. According to statistical study, physical strain has an effect on the performance of nurses at Dr. RSUP. Tadjuddin Chalid. A significance score of 0.000 also indicates a substantial effect, implying that study hypothesis $2(\mathrm{H} 2)$ is adopted in this circumstance.

According to Indriani (2018), the regression coefficient value is -0.164 , indicating that workload has a negative influence on inpatient care performance. The sig value is 0.005 , which is less than the study error rate (0.05), indicating that workload has a substantial impact on inpatient care performance. If the nurse implementing inpatient care can manage his or her physical, psychological, and temporal burdens, the nurse will have an easier time conducting patient assessments, making diagnoses, and planning, executing, and evaluating each task and function as a nurse. If this trend continues, it will have an adverse effect on the performance of inpatient care implementation.

Other workload issues confront nurses when they believe the quantity of nurses available is not related to the amount of work that needs to be performed, forcing them to work outside of 
normal business hours. As a result, they frequently suffer from health problems that result in difficulties sleeping at night, leaving them lethargic and unable to focus at work, quickly weary, and easily angered for no apparent reason. This high workload has a significant impact on the productivity of health care employees, including nurses. According to Griffiths et al. (2008), there are several variables that contribute to the risk of declining performance, one of which is an excessive workload for the available staff/nurses. Meanwhile, Yang (2003) in Armstrong (2009) implies that nurses' workload is a predictor of decreased performance.

The third research hypothesis (H3) asserts that psychological strain has an influence on nurses' performance. According to the statistical study undertaken, it is known that the psychological strain on nurses at Dr. RSUP. Tadjuddin Chalid has an effect on their performance. A significance score of 0.000 also indicates a substantial effect, implying that study hypothesis 3 (H3) is adopted in this circumstance.

According to Marquis and Houston (2000), a nurse's workload is defined as all activities or tasks performed by a nurse while serving in a nursing service unit. The workload is often expressed in terms of patient days, which relates to the number of operations and client visits. Additionally, workload is defined as the entire amount of nursing time spent directly or indirectly delivering nursing services to clients, as well as the number of nurses required to offer these services (Gaudine, 2000).

Workload is a result of the combination between job demands, the work environment in which they are performed, the employees' abilities, conduct, and perceptions (Tarwaka, 2010). It is critical to monitor staff workloads to avoid excessive overtime, which can induce stress and result in decreased employee productivity. The workload used in this study is to ascertain the nurse's perceived perceptions while giving services or nurses to patients, taking into account time constraints, physical demands, and psychological stress.

Workloads can be quantitative or qualitative in nature. Quantitative workloads are dominated by the quantity of work required to fulfill the client's health demands, whereas qualitative workloads are characterized by a high level of responsibility in delivering care to clients. A heavy workload might increase the likelihood of ineffective communication between nurses and patients, a lack of collaboration between nurses and doctors, nurse discharge, job discontent, and lower work effectiveness (Carayon \& Gurses, 2005). According to Ilyas (2004), the heavy workload of nurses might result in weariness and exhaustion. Additionally, Ilyas emphasized tiredness, which happens when nurses work more than $80 \%$ of their shift. In other words, nurses' productive time is around $80 \%$; if it is greater than that, the workload of nurses is regarded excessive or unsuitable, and consideration should be given to increasing the number of nurses in the treatment room.

This is also stated by Moore et al. (2003) in Ronald \& Burke (2003) in their study on acute nursing care, and Armstrong (2003) in Ronald \& Burke (2003) in their study on nurse fatigue, who stated that the workload on nurses is the most significant predictor of the presence of negative mental health in nurses, including stress, lack of job satisfaction, fatigue, and exhaustion.

A high amount of loading results in excessive energy consumption and overstress; on the other hand, a low level of loading results in boredom, saturation, or understress. As a result, it is vital to seek the optimal amount of loading intensity that occurs between these two extremes and, of course, varies across individuals (Zainal, 2011) 


\section{Conclusion}

The results indicated that time load had an influence on nurses' performance and that physical strain had an effect on nurses' performance. Psychological pressure has an influence on the performance of nurses at Dr. RSUP. Tajuddin Chalid Makassar's Inpatient Installation. Thus, it is hoped that hospital administration will enhance nurses' knowledge and skills in order to compensate for the difficult work by providing training, recognizing the importance of improving nursing management through the development of SOPs, particularly the division of tasks and working hours of nurses, which can be adjusted to the nurse's workload.

\section{References}

Carayon, P., A.P. \& Gurses. (2005). Chapter 30. Nursing workload and patient safety-A human factors engineering perspective.

Gaudine, A. P. (2000). What do nurses mean by workload and work overload? Canadian Journal of Nursing Leadership, 13(2), 22-27.

Griffiths, rial G. (2008). Reaserch on Work-related Stress. European. Agency for Safety and Health at Work. Furnham.

Huey, M. Baverly \& Wickens D. (1993). Workload Transition Implication for Individual and Team. Washington DC: National Academy Press.

Indriani, I. (2018). Pengaruh Kompetensi dan Beban Kerja Terhadap Kinerja Pelaksanaan Asuhan Keperawatan Pada Bagian Rawat Inap Rumah Sakit Umum Dr. Slamet Garut. Jurnal Wacana Ekonomi, 17(2), 025-032.

Iswatun, (2013). Hubungan Beban Kerja dan Motivasi Kerja dengan Kinerja Perawat di RSUD. Soegiri Lamongan. Jurnal Universitas Sebelas Maret Surakarta

Mangkunegara, A. P. (2013). Manajemen sumber daya manusia perusahaan. (Cetakan ketiga). Bandung: PT. Remaja Rosdakarya Offset.

Marquis, B. L. dan Huston, C. J. (2000). Leaderships roles and management functions in nursing. (3rd ed). Philadelphia: Lippincot -Raven Publisher.

Ronald \& Burke, (2003). Advancing women's careers. Career Development International, 10(3):165-167.

Samiadji. (2016). Pengaruh Stres Kerja Terhadap Kinerja Perawat Melalui Kepuasan Kerja . Manajemen \& Bisnis Jurnal.

Shah, Syed et al., (2011). Workload and Performance of Employees. Journal of Contemporary Research in Business, 3(5):256- 267.

Sihotang. (2011). Manajemen Sumber Daya Manusia. Jakarta: Pradnya Paramita

Tarwaka. (2010). Ergonomi Industri. Dasar-Dasar Pengetahuan Ergonomi Dan Aplikasi Di Tempat Kerja. Harapan Press : Surakarta. 